\title{
Multiple shoot induction and regeneration of Vanilla borneensis Rolfe - a critically endangered orchid of Assam, India
}

\author{
Sneha Hasnu \& Bhaben Tanti* \\ Plant Molecular Biology Laboratory, Department of Botany, Gauhati University, Guwahati 781 014, Assam, India \\ *Email: btanti@gauhati.ac.in
}

OPEN ACCESS

\section{ARTICLE HISTORY}

Received: 03 June 2021

Accepted: 03 November 2021

Available online

Version 1.0 (Early Access): 21 November 2021 Version 2.0:01 January 2022

\section{Check for updates}

\section{Additional information}

Peer review: Publisher thanks Sectional Editor and the other anonymous reviewers for their contribution to the peer review of this work.

Reprints \& permissions information is available at https://horizonepublishing.com/ journals/index.php/PST/open_access_policy

Publisher's Note: Horizon e-Publishing Group remains neutral with regard to jurisdictional claims in published maps and institutional affiliations.

Indexing: Plant Science Today, published by Horizon e-Publishing Group, is covered by Scopus, Web of Science, BIOSIS Previews, Clarivate Analytics, etc. See https:// horizonepublishing.com/journals/index.php/ PST/indexing_abstracting

Copyright: $(\subset)$ The Author(s). This is an openaccess article distributed under the terms of the Creative Commons Attribution License, which permits unrestricted use, distribution and reproduction in any medium, provided the original author and source are credited (https://creativecommons.org/licenses/ by/4.0/)

\section{CITE THIS ARTICLE}

Hasnu S, Tanti B . Multiple shoot induction and regeneration of Vanilla borneensis Rolfe a critically endangered orchid of Assam, India. Plant Science Today. 2022;9(1):96-104. https://doi.org/10.14719/pst.1292

\begin{abstract}
In the present investigation, a micropropagation protocol has been developed for Vanilla borneensis - a critically endangered orchid through multiple shoot regeneration. Significantly, in vitro multiple shoot regeneration from both nodal and shoot tip explants revealed $100 \%$ shoot induction. The minimum time required for shoot bud induction was observed from the shoot tip (5-6 days) on MS medium supplemented with 6-Benzylaminopurine (BAP) (4.44 mM) + Kinetin (KIN) (2.32 mM) as compared to the nodal explants on medium supplemented with BAP $(4.44 \mathrm{mM})+$ Thidiazuron (TDZ) (6.82 $\mathrm{mM})$. Maximum multiple shoot regeneration was observed from nodal explants on the medium supplemented with BAP (4.44 mM) + TDZ (6.82 mM). However, maximum shoot length $(6.35 \mathrm{~cm})$ was observed on the medium supplemented with BAP $(4.44 \mathrm{mM})+15 \% \mathrm{CW}$ (coconut water) and the number of nodes $(5.27 \pm 0.33)$ per shoot after 90 days. $100 \%$ root initiation was observed in the concentration of NAA $(5.37 \mu \mathrm{M})$. The shortest time of root initiation was found on the medium supplemented with a concentration of $5.37 \mathrm{mM}$ NAA. Further, acclimatization period was found to be 15 days with $70 \%$ acclimatization while $60 \%$ of survival rate was observed in the field condition. This efficient micropropagation method of $V$. borneensis could be successfully used for mass propagation as well as conservation of the critically endangered wild orchid.
\end{abstract}

\section{Keywords}

acclimatization, conservation, critically endangered orchid, micropropagation, multiple shoot regeneration, Vanilla borneensis

\section{Introduction}

Vanilla borneensis is a monopodial terrestrial climbing orchid native to Southeast Asia (1). It was first described from Malaya and also found to occur naturally in certain parts of Malay Peninsula, Thailand and in dry evergreen hilly forests of Assam at an elevation ranging from sea level up to 1000 $\mathrm{m}$ (2). In India, this plant was reported for the first time from Nambar Reserve Forest of Golaghat District and Lahorijan Reserve Forest of Karbi Anglong. Vanilla borneensis has been reported as a rare, endemic and threatened orchid species of Assam, India $(3,4)$. One of the recent similar findings of also stated that $V$. borneensis is a critically endangered orchid which needs to be conserved as soon as possible (5). At present, the condition of this plant is such that its population stock in the natural habitat is depleting very fast due to human interferences for habitat fragmentation and over exploitation which ultimately hinders the propagation of the plant in its 
natural condition.

The genus Vanilla is also known for its artificial means of pollination technique generally fulfilled by hand pollination as their flower is designed in such a way that the 'rostellum' is found to be lying in between the male pollen flip and the stigma. This rostellum acts as the barrier due to which the flower is unable to self pollinates and also no pollinators are known to pollinate vanilla flowers to date except rarely found melipona bees in its place of origin Mesoamerica (6). Today even the vanilla cultivators of Mexico are extensively going for hand pollination method for higher production of natural vanilla beans. But then, the matured pods bearing seeds are not viable to produce plantlets for supporting their population stock. It is because the Vanilla species produce many small seeds without endosperm and has low germination rate under natural conditions same as the seeds of other orchid species (7).

A macropropagation technique has already been reported for $V$. borneensis (3). However in such case the mother plant gets depleted due to cuttings made for propagation apart from the other causes like habitat destruction and over exploitation. No alternative way for propagation and conservation of the plant has been reported yet. If we throw light on its relative cultivated species like $V$. planifolia, $V$. pompon and $V$. tahitensis then, we will find a number of reports of their utility in different fields and in the service of mankind. Vanilla species is popularly known for its distinct aromatic scent and flavor which is due to the presence of the main component 'Vanillin' alongside with its derivatives. Thus, these components are used as a food additive in many delicacies and also be used in medicines. The aroma is the result of curing process of green vanilla beans to cured one. Unfortunately, the uses or the application of current plant in question has no significant report yet and the few reports available are regarding its conservation strategies. The conservation reports present are those dealing with macropropagation which directly hampers the growth of its mother plant. In order to overcome this problem a significant micropropagation protocol has to be developed immediately, meeting the needs of its conservation purpose and also to support further research in different fields. The future of the plant lies with its existence and hence mass propagation of its population stock by optimizing an efficient micropropagation technique is utmost necessary. Therefore, the present study is emphasized upon the multiple shoot regeneration from the nodal and shoot apex explants of $V$. borneensis.

\section{Materials and Methods}

Plant material, collection of explants and surface sterilization

The raw materials were collected from Lahorijan Reserve forest, Karbi Anglong district, Assam. Cuttings of the plant materials were allowed to grow in the poly-bags for regular maintenance and long term use as the source of explants in the greenhouse of the Department of Botany, Gauhati University, India. Frequent monitoring was done to ensure shoot induction and its healthy growth. After two weeks, new shoots emerges out singly from each node. The shoots with 3-4 nodes and young delicate leaflets were available after the $4^{\text {th }}$ week of plantation. These sources were used as explants including nodes and shoot apex.

The explants were washed properly and carefully under running tap water to remove dust and soil particles which were followed by wash in $0.05 \%$ Tween 20 for 10 min. The explants were then washed with $1 \%$ Sodium hypochlorite for 5-7 min which was then suspended in 1\% bavistin for $10 \mathrm{~min}$. The explants were then washed with double distilled water for 3 - 4 times. Surface sterilization of the explants was done in the laminar air flow with $0.1 \%$ $\mathrm{HgCl}_{2}$ for 10 min and finally rinsed with sterile distilled water for 3-4 times $(8,9)$.

\section{Establishment of in vitro shoot culture}

The sterilized explants were cultured on the MS media supplemented with $3 \% \mathrm{w} / \mathrm{v}$ sucrose, coconut water (15\% of MS), plant growth regulators such as auxin (NAA) and cytokinins (BAP, TDZ, Kinetin), and gelled with $0.8 \% \mathrm{w} / \mathrm{v}$ agar; $\mathrm{pH}$ was maintained at 5.8 and autoclaved at $121{ }^{\circ} \mathrm{C}$ for 20 $\min$ at $15 \mathrm{lb}$ pressure (10). The cultures were then maintained at $25 \pm 2{ }^{\circ} \mathrm{C}$ and $60-70 \%$ relative humidity with 3000 lux light intensity for $16 \mathrm{hrs}$ light and $8 \mathrm{hrs}$ dark condition. Each treatment was repeated thrice with five replicas per treatment at 1 month interval $(11,12)$.

\section{Shoot initiation and multiplication}

For shoot initiation and its further multiplication, the nodal and shoot apex explants were cultured on MS media $(\mathrm{pH}$ 5.8) supplemented with $\operatorname{BAP}(2.22,4.44,8.88,11.1 \mu \mathrm{M}), \mathrm{KIN}$ $(2.32,4.65,6.97 \mu \mathrm{M})$, and TDZ $(2.27,4.55,6.825 \mu \mathrm{M})$ in different combinations and coconut water (15\% of MS media). The parameters, i.e., percentage of shoot initiation, number of days taken for shoot initiation were recorded after 30 days and number of shoots per explants, number of nodes per shoot and shoot length $(\mathrm{cm})$ were taken at the interval of 45 days and 90 days.

\section{In vitro root initiation}

The micro shoots obtained from in vitro multiplication were cultured on full strength MS media containing NAA of concentrations $2.68 \mu \mathrm{M}, 5.37 \mu \mathrm{M}, 8.05 \mu \mathrm{M}, 10.7 \mu \mathrm{M}, 13.4 \mu \mathrm{M}$ and IBA of $2.46 \mu \mathrm{M}, 4.92 \mu \mathrm{M}, 7.38 \mu \mathrm{M}, 9.84 \mu \mathrm{M}, 12.30 \mu \mathrm{M}$. The parameters observed were percentage of root initiation, number of days taken for root initiation, number of roots per shoot and root length $(\mathrm{cm})$.

\section{Acclimatization and hardening}

The well developed shoots with roots were transferred to sterilized soilrite (mixture of expanded perlite, Irish Peat moss and exfoliated vermiculite in equal ratio) for acclimatization. Before transferring the rooted plantlets were washed with sterilized water and the agar was carefully removed. The plantlets were then covered with sterilized poly bags for keeping humidity. The poly-bags were perforated after 8-10 days and kept in the culture room for 25-30 days.

For hardening purpose, the well acclimatized plants 
were transferred to potting mixture containing garden soil in the nodal explants grown on media boosted with BAP (40\%), sand (25\%), cocopeat (10\%) and cow manure (25\%) $(2.22 \mu \mathrm{M})+15 \% \mathrm{CW}$, BAP $(4.44 \mu \mathrm{M})+\mathrm{NAA}(5.37 \mu \mathrm{M})$, BAP under greenhouse condition for 20 - 25 days. The plantlets $(4.44 \mu \mathrm{M})$ and $\operatorname{KIN}(2.32,4.65 \mu \mathrm{M})$ and $\mathrm{BAP}(2.22,4.44 \mu \mathrm{M})+$ were then transferred to shade house for 6-10 days, after TDZ $(2.27,4.55,6.82 \mu \mathrm{M})$. For shoot tip explants, total shoot which they were finally planted in the field and monitored initiation was found on the media supplemented with frequently. The acclimatization stage of $V$. borneensis was different combinations of BAP $(4.44,6.66 \mu \mathrm{M})+\mathrm{CW}(15 \%$ of successfully implemented at low air temperature $\left.\left(17-25^{\circ} \mathrm{C}\right) \quad \mathrm{MS}\right), \operatorname{BAP}(4.44 \mu \mathrm{M})+\mathrm{NAA}(5.37 \mu \mathrm{M}), \mathrm{BAP}(4.44 \mu \mathrm{M})+\mathrm{KIN}$ and low relative humidity $(55 \pm 2 \% \mathrm{RH})$.

\section{Statistical analysis}

The experiments were conducted with 5 replicates per treatment and repeated for thrice. Considering each replicate as an experimental unit, data were recorded as mean \pm standard deviation and subjected to one way ANOVA after which the difference between the treatments were tested by Duncan's multiple range test (DMRT) at $p \leq 0.05 \%$ (13) .

\section{Results}

\section{Shoot initiation}

Shoot initiation was clearly observed in the nodal as well as shoots tip explants. Shoot initiation was found to be $100 \%$ $(2.32 \mu \mathrm{M}), \operatorname{BAP}(6.66 \mu \mathrm{M})+\operatorname{TDZ}(2.27 \mu \mathrm{M})$ and $\operatorname{BAP}(4.44 \mu \mathrm{M})$ only (Table 1$)$. The nodal explants grown on the medium boosted with BAP $(4.44 \mu \mathrm{M})$ and TDZ $(6.82 \mu \mathrm{M})$ took minimum $(05.93 \pm 0.21)$ days for initiation of shoots. The media containing BAP $(4.44 \mu \mathrm{M})$ and $\operatorname{KIN}(2.32 \mu \mathrm{M})$, shoot tip explants took minimum days of $(05.60 \pm 0.23)$ for fresh initiation of multiple shoots (Table 1 ). It was found that for both the explants, BAP with optimum $4.44 \mu \mathrm{M}$ with any combination was found shoot initiation potential in short period. Gradual increase in BAP concentration causes requirement of longer days for initiating new shoots and in that case only few explants responded to it. Auxin and cytokinin in combination was found to initiate both shoot and root. In that case the growth of the root overtook the pace and the growth of the shoot gets retarded. Therefore, use of only

Table 1. Effect of BAP, NAA, Kinetin, TDZ and CW in shoot initiation from nodal and shoot tip explants on MS media

\begin{tabular}{|c|c|c|c|c|c|c|c|c|}
\hline \multicolumn{5}{|c|}{ Concentration of Plant growth regulators $(\mu \mathrm{M})$} & \multicolumn{2}{|c|}{ Nodal segment } & \multicolumn{2}{|c|}{ Shoot tip } \\
\hline BAP & CW (\%) & NAA & KIN & TDZ & Bud initiation (\%) & Days to bud initiation & Bud initiation (\%) & Days to bud initiation \\
\hline 2.22 & 15 & - & - & - & $100.0 \pm 0.00^{\mathrm{a}}$ & $11.13 \pm 0.30^{\mathrm{a}}$ & $93.33 \pm 0.24^{\mathrm{ab}}$ & $10.13 \pm 0.17^{c}$ \\
\hline 4.44 & 15 & - & - & - & $93.33 \pm 0.24^{\mathrm{a}}$ & $08.00 \pm 0.41^{\mathrm{a}}$ & $100.0 \pm 0.00^{\mathrm{a}}$ & $07.20 \pm 0.32^{\mathrm{d}}$ \\
\hline 6.66 & 15 & - & - & - & $86.67 \pm 0.47^{\mathrm{a}}$ & $09.70 \pm 0.36^{a}$ & $100.0 \pm 0.00^{\mathrm{a}}$ & $09.87 \pm 0.28^{c}$ \\
\hline 8.88 & 15 & - & - & - & $80.00 \pm 0.71^{\mathrm{a}}$ & $12.13 \pm 0.09^{a}$ & $80.00 \pm 0.35^{b c}$ & $11.73 \pm 0.25^{b}$ \\
\hline 11.1 & 15 & - & - & - & $73.33 \pm 0.59^{a}$ & $14.00 \pm 0.10^{\mathrm{a}}$ & $66.67 \pm 1.18^{c}$ & $13.87 \pm 0.23^{\mathrm{a}}$ \\
\hline 2.22 & - & 2.68 & - & - & $86.67 \pm 0.47^{\mathrm{ab}}$ & $08.60 \pm 0.45^{d}$ & $93.33 \pm 0.24^{\mathrm{ab}}$ & $11.50 \pm 0.32^{c}$ \\
\hline 4.44 & - & 5.37 & - & - & $100.0 \pm 0.00^{a}$ & $10.80 \pm 0.46^{d}$ & $100.0 \pm 0.00^{\mathrm{a}}$ & $09.47 \pm 1.07^{\mathrm{d}}$ \\
\hline 6.66 & - & 8.05 & - & - & $93.33 \pm 0.24^{\mathrm{ab}}$ & $13.67 \pm 0.55^{c}$ & $86.67 \pm 0.47^{a b}$ & $12.93 \pm 0.68^{c}$ \\
\hline 8.88 & - & 10.7 & - & - & $80.00 \pm 0.47^{\mathrm{ab}}$ & $16.00 \pm 0.62^{b}$ & $86.67 \pm 0.59^{b}$ & $15.80 \pm 0.30^{\mathrm{b}}$ \\
\hline 11.1 & - & 13.4 & - & - & $93.00 \pm 0.24^{b}$ & $18.00 \pm 0.46^{a}$ & $93.33 \pm 0.24^{\mathrm{ab}}$ & $17.93 \pm 0.70^{\mathrm{a}}$ \\
\hline 2.22 & - & - & 2.32 & - & $80.00 \pm 0.71^{\mathrm{a}}$ & $08.47 \pm 0.18^{\mathrm{a}}$ & $86.67 \pm 0.47^{\mathrm{ab}}$ & $07.60 \pm 0.21^{c}$ \\
\hline 2.22 & - & - & 6.97 & - & $93.33 \pm 0.59^{\mathrm{a}}$ & $07.27 \pm 0.18^{\mathrm{a}}$ & $60.00 \pm 1.06^{b}$ & $07.07 \pm 0.18^{\mathrm{a}}$ \\
\hline 4.44 & - & - & 2.32 & - & $100.0 \pm 0.00^{\mathrm{a}}$ & $06.27 \pm 0.21^{\mathrm{ab}}$ & $100.0 \pm 0.00^{\mathrm{ab}}$ & $05.60 \pm 0.23^{b}$ \\
\hline 4.44 & - & - & 4.65 & - & $100.0 \pm 0.00^{\mathrm{a}}$ & $08.20 \pm 0.19^{c}$ & $93.33 \pm 0.24^{\mathrm{a}}$ & $08.27 \pm 0.17^{d}$ \\
\hline 6.66 & - & - & 2.32 & - & $86.67 \pm 0.47^{\mathrm{a}}$ & $08.80 \pm 0.18^{b c}$ & $80.00 \pm 0.70^{c}$ & $09.53 \pm 0.20^{c}$ \\
\hline 2.22 & - & - & - & 4.55 & $80.00 \pm 0.70^{\mathrm{ab}}$ & $08.60 \pm 0.15^{\mathrm{a}}$ & $93.33 \pm 0.24^{b}$ & $08.80 \pm 0.20^{\mathrm{a}}$ \\
\hline 2.22 & - & - & - & 6.82 & $100.0 \pm 0.00^{\mathrm{b}}$ & $05.93 \pm 0.21^{c}$ & $80.00 \pm 0.70^{a}$ & $06.13 \pm 0.24^{c}$ \\
\hline 4.44 & - & - & - & 2.27 & $100.0 \pm 0.00^{\mathrm{ab}}$ & $05.80 \pm 0.06^{c}$ & $86.67 \pm 0.47^{a}$ & $07.27 \pm 0.28^{b}$ \\
\hline 4.44 & - & - & - & 4.55 & $100.0 \pm 0.00^{\mathrm{ab}}$ & $07.27 \pm 0.21^{b}$ & $93.00 \pm 0.24^{\mathrm{a}}$ & $06.87 \pm 0.18^{\mathrm{b}}$ \\
\hline 6.66 & - & - & - & 2.27 & $93.33 \pm 0.24^{\mathrm{a}}$ & $07.47 \pm 0.16^{b}$ & $100.0 \pm 0.00^{\mathrm{a}}$ & $08.73 \pm 0.18^{a}$ \\
\hline 4.44 & - & - & - & - & $100.0 \pm 0.00^{\mathrm{a}}$ & $07.53 \pm 0.59^{\mathrm{e}}$ & $100.0 \pm 0.00^{\mathrm{a}}$ & $07.73 \pm 0.46^{d}$ \\
\hline 6.66 & - & - & - & - & $93.33 \pm 0.23^{\mathrm{ab}}$ & $10.67 \pm 0.23^{d}$ & $93.33 \pm 0.24^{\mathrm{a}}$ & $11.33 \pm 0.11^{c}$ \\
\hline 8.88 & - & - & - & - & $80.00 \pm 0.71^{\mathrm{ab}}$ & $14.70 \pm 0.62^{b}$ & $86.67 \pm 0.47^{a}$ & $15.00 \pm 0.63^{b}$ \\
\hline 11.1 & - & - & - & - & $73.33 \pm 0.47^{b}$ & $16.00 \pm 0.46^{\mathrm{a}}$ & $80.00 \pm 0.71^{\mathrm{a}}$ & $17.00 \pm 0.43^{a}$ \\
\hline
\end{tabular}

Values are Mean \pm SD of five replicates from three repeated experiments. Means with same superscript within each column are not significantly different at $p$ $\leq .05$ according to Duncan's multiple range test (DMRT) 
cytokinin in the beginning of culture was needed for initiat- $5.27 \pm 0.33$ number of nodes per shoot when cultured on BAP ing new shoots and their proliferation prior to initiation of $(4.44 \mu \mathrm{M})+15 \% \mathrm{CW}$ supplemented medium [Fig. 1 (d - f)]. roots. There was neither shoot nor was root initiation ob- Again the media boosted with BAP and coconut water (CW) served in PGR free medium.

\section{Shoot multiplication and proliferation}

There was no significant multiplication of shoots from shoot tip explants. Therefore, further study on multiplication of shoot was carried out in the nodal explants. The nodal explants cultured on MS media boosted with BAP in combination with any one of CW, KIN, NAA and TDZ resulted into multiple growths of shoots. However, BAP and TDZ are found to be more efficient in this regard. Highest number of multiple shoots was observed on the media boosted with BAP $(2.22 \mu \mathrm{M})+$ TDZ $(6.82 \mu \mathrm{M})$. This combination resulted $5.53 \pm 0.17$ number of shoots after 45 days of culture, which was then increased to $11.8 \pm 0.27$ numbers of shoots after 90 days. In this combination, the shoots exhibited relatively low height and less number of nodes per shoot. The shoot length exceeded to maximum $6.35 \pm 0.12 \mathrm{~cm}$ with resulted into very less number of shoots $(1.60 \pm 0.17)$ in 90 days of culture. However, the number of shoots generated didn't have much increase even after 90 days of culture and the number was $4.87 \pm 0.16$ and the maximum length of the shoot recorded was $4.08 \pm 0.11 \mathrm{~cm}$ (Table 2). In this hormone combination, the multiplication of shoot was not observed. The media boosted with BAP $(4.44 \mu \mathrm{M})+\mathrm{KIN}$ $(2.22 \mu \mathrm{M})$ showed a positive response to multiplication of shoot with maximum $4.00 \pm 0.27$ numbers after 45 days of culture. The medium boosted with BAP and NAA showed minimum multiplication of shoots even after subsequent sub-culture. In this case, highest number of shoot was found in the combination of BAP $(4.44 \mu \mathrm{M})+$ NAA $(5.37 \mu \mathrm{M})$ with $1.53 \pm 0.49$ number after 45 days of culture which increased into $2.33 \pm 0.32$ numbers after 90 days of culture. Initiation of root was also observed in this combination which actually hinders normal growth of the shoots.

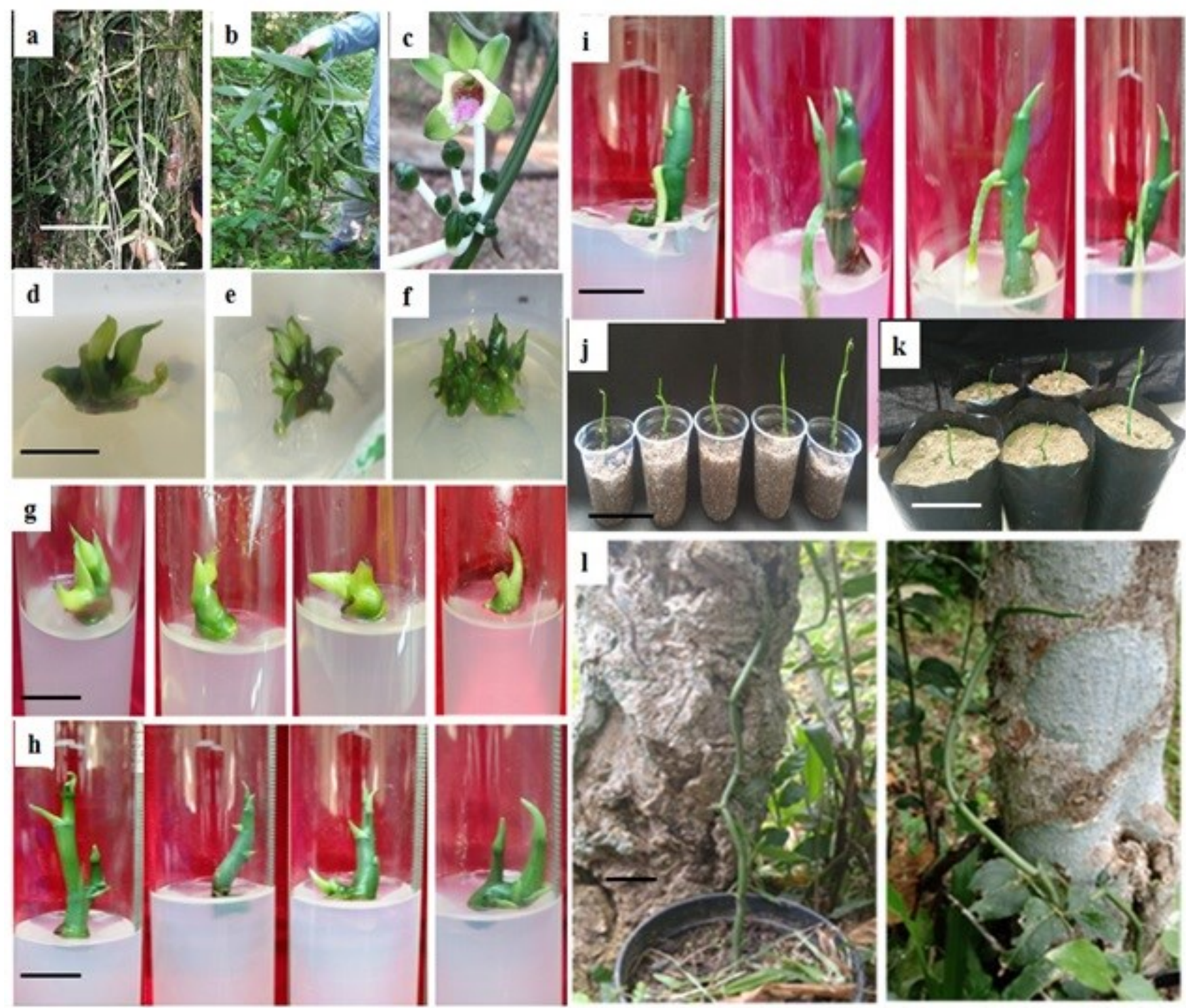

Fig. 1. (a) Vanilla borneensis plant at natural habitat of Lahorijan reserve forest, Karbi Anglong, Assam (India) (b) Sample collected for cuttings to be done in the green house, (c) Flowering stage of $V$. borneensis, (d-f) Shoot bud induction and multiplication from nodal segment on MS media supplemented with BAP(4.44 $\mu \mathrm{M})+\mathrm{TDZ}(6.825 \mu \mathrm{M}),(\mathbf{g}-\mathbf{h})$ Individual shoot elongation on MS $+4.44 \mu \mathrm{M} \mathrm{BAP}+15 \% \mathrm{CW}$ (i) Rooting of shoots in MS + $5.37 \mu \mathrm{M}$ NAA (j) Primary acclimatized plantlets in autoclaved soil rite, (k) Final acclimatized plantlets in soil + cow manure + sand, (l) Well survived plants in the field $(\mathrm{Bar}=1 \mathrm{~cm})$. 
Table 2. Multiple shoot proliferation in V. borneensis using nodal segment on MS media

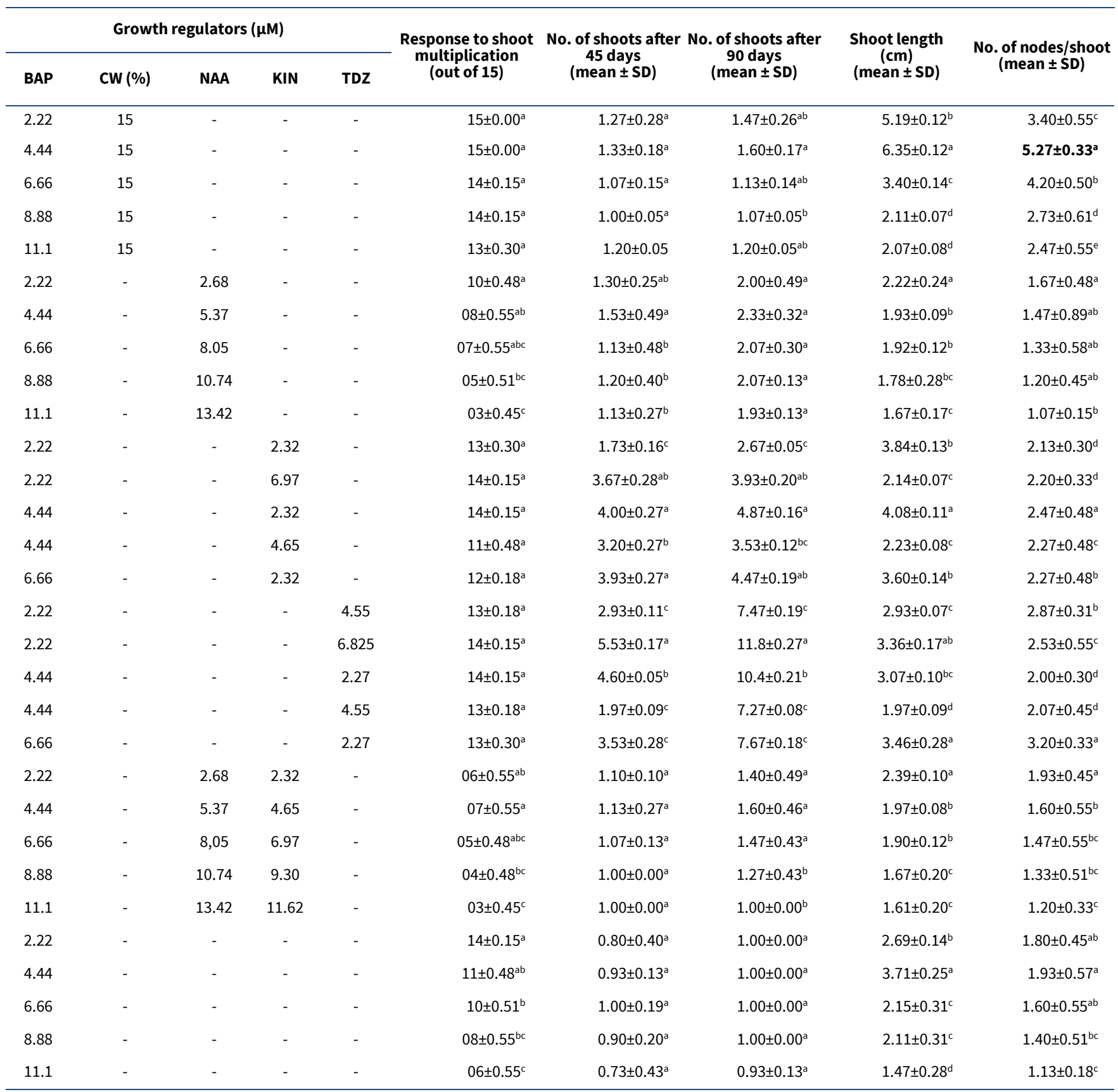

Values are Mean \pm SD of five replicates from three repeated experiments. Means with common superscript within each column are not significantly different at $\mathrm{p} \leq .05$ according to Duncan's multiple range test (DMRT)

The explants grown on the medium supplemented multiplication of $V$. borneensis in vitro affected the explants with BAP, NAA and KIN responded slowly and with minimal on shoot growth. number of shoots. Highest number of shoot was found in combination of BAP $(4.44 \mu \mathrm{M})+\mathrm{NAA}(5.37 \mu \mathrm{M})+\mathrm{KIN}(4.65$ $\mu \mathrm{M}$ ) with $1.13 \pm 0.27$ in 45 days and $1.60 \pm 0.46$ numbers in 90 days. Incident of root initiation and proliferation were also seen in this condition which might be hindering the growth of shoots.

The cytokinin BAP, when used alone in different concentration resulted in only one shoot per explants. The medium boosted with BAP $(4.44 \mu \mathrm{M})$ showed the highest shoot length of $(3.71 \pm 0.25 \mathrm{~cm})$ and number of nodes $(1.93 \pm 0.57)$ per shoot in 90 days of culture. However, as the BAP concentration was increased, gradual decrease in shoot growth and length was seen (Table 2). Here, the coconut water (CW) in combinations with cytokinins on proliferation and

\section{Root initiation and proliferation}

The healthy shoots obtained from multiple shoots were cultured on medium containing NAA and IBA in different concentrations. $80-100 \%$ root initiation was observed in all the given concentration of NAA while $53-100 \%$ of root initiation revealed in presence of IBA. The culture supplemented with NAA $(5.37 \mu \mathrm{M})$ showed initiation of maximum root growth $(100 \%)$ in minimum time period $(5.8 \pm 0.48$ days). Total number of root was found to be $1.53 \pm 0.55$ and root length was $4.33 \pm 0.23 \mathrm{~cm}$ in the same concentration of NAA [Fig. 1(i)]. Higher concentration of NAA (8.05, $10.7,13.4 \mu \mathrm{M}$ ) resulted into less number of root induction and root length which also required longer duration of time (Fig. 2). Shoots cultured in the medium supplement- 

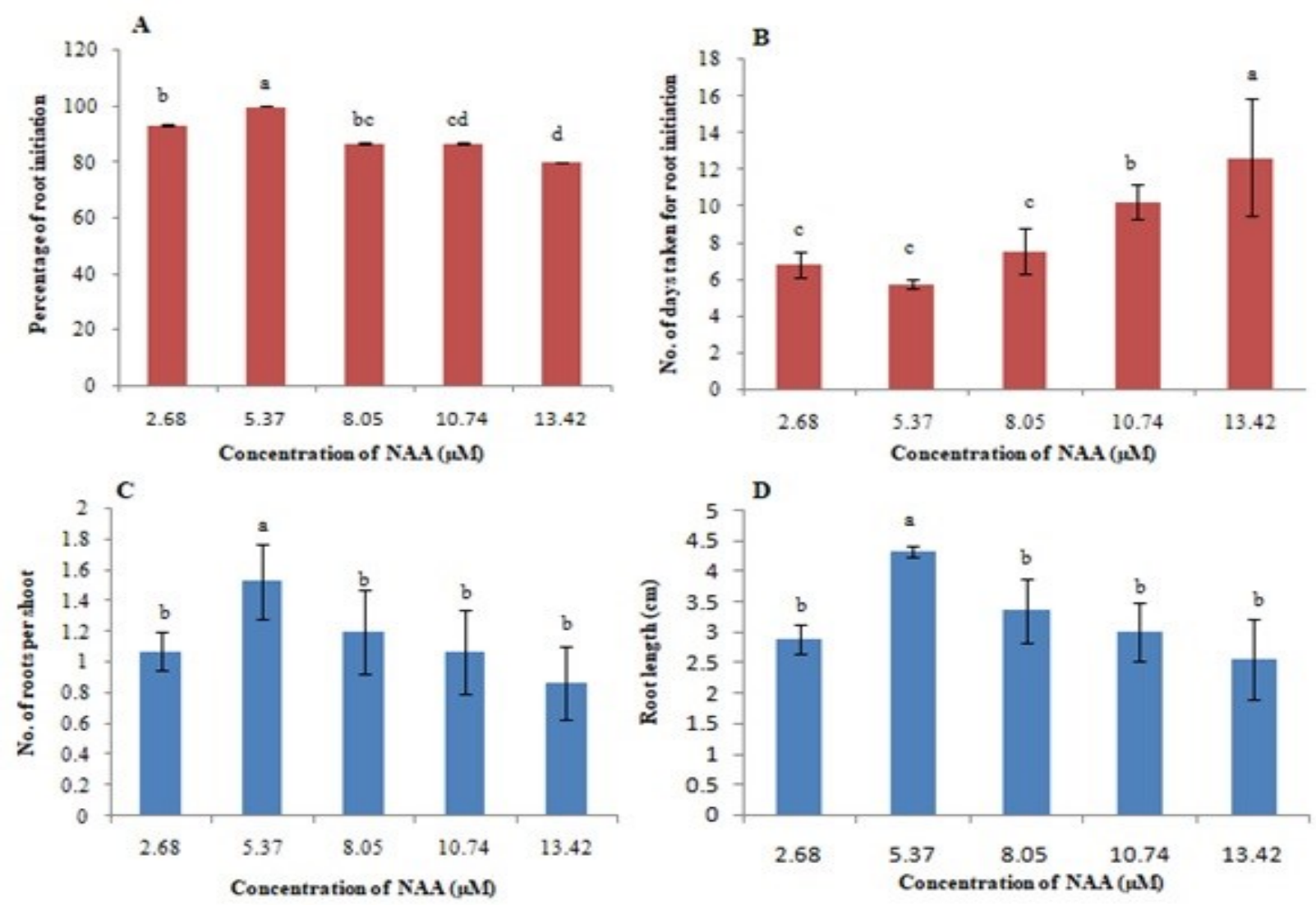

Fig. 2. Effect of NAA on (A) percentage of root initiation (B) the number of days taken for root initiation (C) number of roots (D) root length (cm) on full strength MS media

ed with $4.92 \mu \mathrm{M}$ IBA gave rise to $100 \%$ root initiation ed with $4.92 \mu \mathrm{M}$ of IBA. The rest of the applied concentrawhich took minimum $17.67 \pm 0.60$ number of days. Larger tion of IBA did not showed any significant result as compart of the given concentration of IBA resulted into a very pared to that of the root growths obtained from the media poor root initiation and its development. The maximum boosted with NAA. However, it was significant that, with mean number of root was obtained as $1.0 \pm 0.00$ and the the rise in application of IBA concentration in the media maximum mean root length was obtained as $1.39 \pm 0.07$ the root growth gradually drops its count to a very less $\mathrm{cm}$ when the shoots were cultured on the medium boost- number which was negligible (Fig. 3).
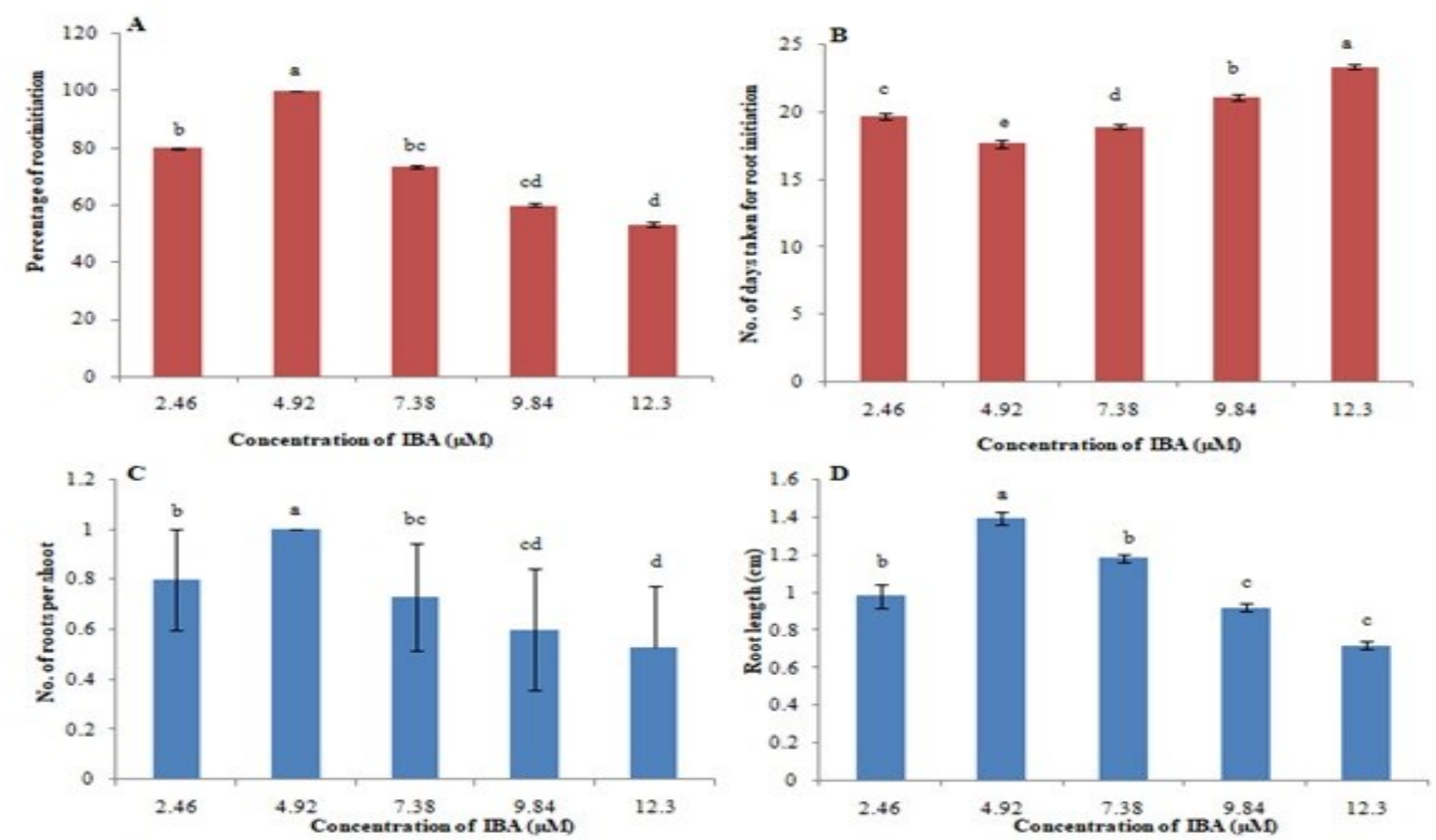

Fig. 3. Effect of IBA on (A) percentage of root initiation (B) the number of days taken for root initiation (C) number of roots (D) root length (cm) on full strength MS media. 


\section{Acclimatization}

The healthy rooted plantlets were taken out from the culture tubes and washed carefully and thoroughly with distilled water to remove the remaining agar. The plantlets were allowed to grow on sterile soilrite, covered with plastic bags to maintain relative humidity in the culture room. Frequent watering was done which showed to increase their height along with the initiation of tiny leaves within 10 -15 days. The plastic covering of the planted glasses were then perforated to lower the humidity. After 30-45 days the plantlets were transferred to poly bags containing garden soil, cow manure and sand (2:1:1) and kept inside the culture room for 7-10 days more. The well acclimatized plants were then taken to the greenhouse for a period of 20 days, conditioned with 60-70\% humidity and $25 \pm 2{ }^{\circ} \mathrm{C}$ temperature and monitored frequently. Within 15-17 days, the plants appeared with new tiny leaves and increase in its height and new tiny leaves. $60 \%$ of plantlets were survived under the greenhouse condition. In the field, survival of $60 \%$ plants was observed [Fig. 1 (j, k, l)].

\section{Discussion}

This study has revealed some interesting and positive outcomes from the in vitro multiple shoot regeneration. This is the first report on in vitro micropropagation of Vanilla borneensis. Till date, many reports has been forwarded by different authors regarding the micropropagation of mostly cultivated Vanilla species viz. V. planifolia Andr., V. pompona Schiede and $V$. tahitensis Moore $(14,15)$.

Cytokinins are very well known to induce shooting in addition to multiplication of the given explants and cytokinin when combined along with auxin generally results into callus induction. Indirect organization through callus initiation from leaf and nodal explants in V. planifolia was reported by researchers $(16,17)$ where, the media supplemented with BAP and NAA showed a positive response in multiplication increase in number of plantlets. Likewise, for direct shoot initiation and multiplication from nodal and shoot tip explants, cytokinins like BAP, Kinetin, TDZ were extensively used by many workers (18-20). In the present study, different concentrations and combinations of cytokinins alone are studied rather than using both cytokinin and auxin (except NAA) for direct initiation of multiple shoots and its proliferation. The minimum 45 days required for fresh shoot initiation in case of shoot tip explants while multiple shoot induction was found by nodal explants. This is in agreement with some previous findings where, the author has reported an effective protocol for initiation and multiplication of shoots in $V$. planifolia through nodal explants (21). This study also reported with optimum application of BAP $(4.44 \mu \mathrm{M})$ for effective shoot initiation and its rapid growth. Similarly, supplementary application of NAA $(2.68 \mu \mathrm{M}, 5.37 \mu \mathrm{M})$ proved to be more effective for growth and initiation of root finding similarity with already published report (22). The MS media supplemented with cytokinin alone and without the auxin was enough for initiation of shoot in addition to its multiplication. An important point can be noted out from the current study that the gradual increase in application of BAP resulted in moderate decrease in growth and multiplication of shoot which can be compared with micropropagation of V. planifolia(23-25). The current study also revealed positive response like fast shoot initiation and rapid shoot elongation when coconut water (15\% of MS media) was added along with BAP in different concentration. This kind of positive response might have obtained because coconut water contains natural cytokinine and composed of many other important phytohormones, vitamins, sugars, inorganic ions and minerals (26). However, multiplication of shoots was not seen in this combination. Use of coconut water in micropropagation of $V$. planifolia was reported in previous studies $(22,27)$. Addition of kinetin along with BAP in the culture media showed comparatively favorable response to shoot initiation and multiplication. Kinetin with lowest concentration $(2.32 \mu \mathrm{M})$ when added along with BAP $(4.44 \mu \mathrm{M})$ revealed an optimum result with shorter time for initiation of shoot (within 5-6 days) and its multiplication (4-6 shoots). It was also observed that kinetin alone has a negligible effect in shoot bud initiation and multiplication (28). The media supplemented with BAP and TDZ in different concentration was equally significant in shoot initiation and multiplication. In point of fact, the current study witnessed the elevated number of induced multiple shoots $(11.8 \pm 0.27)$ from the nodal explants when cultured in the media boosted with BAP $(2.22 \mu \mathrm{M})$ and TDZ $(6.82 \mu \mathrm{M})$. Minimum 5-6 days were required for fresh shoot initiation and $100 \%$ response was seen from the nodal explants. However, the length of the shoot could not be achieved more than $(3.36 \pm 0.17) \mathrm{cm}$. This might be due to TDZ because it is known for inhibition of shoot elongation as reported in apple, Albizia and cassava (29-31).

Induction of root and its proliferation was actively prevailed on the full strength MS media boosted with distinct concentration of NAA $(2.68,5.37,8.05,10.7,13.4 \mu \mathrm{M})$. Elevation in NAA concentration simultaneously decreases the root induction capability and also requires longer duration of time. Similar kind of observation and optimization was derived from previous report $(32,33)$, where MS media combined with $1 \mathrm{mgl}^{-1} \mathrm{NAA}$ developed into $83.3 \%$ rooting with maximal root length of $4.42 \pm 0.2 \mathrm{~cm}$ and roots per shoot of $3.29 \pm 0.3$ was observed. While in the same study use of IBA $\left(2 \mathrm{mgl}^{-1}\right)$ resulted into $76.7 \%$ of rooting with mean root length of $3.51 \pm 0.2 \mathrm{~cm}$ and mean root number of $2.34 \pm$ 0.2 . However, in the current study, the micro shoots cultured on the media boosted with IBA showed comparatively lesser significant result than that of the shoots cultured on media boosted with NAA. The concentration of $4.92 \mu \mathrm{M}$ of IBA resulted $100 \%$ of root initiation within minimum $17-$ 18 days of culture. The maximum length of the root could not exceed more than $1-2 \mathrm{~cm}$ obtained in the optimum concentration of $4.92 \mu \mathrm{M}$. A significant common response was observed during the application of both the hormones, i.e., with gradual rise in application of both the hormones, there was a moderate fall in the positive response of root growth from the cultured shoots. Thus, it was evident from the current study that application of NAA for proper root growth was more beneficial than that of the IBA application (34-36). 
Successful acclimatization of the healthy plantlets can be attributable to maintenance of elevated humidity during the whole process as this particular species needs humidity for its survival. Vanilla plants require moderate shade and temperature between $20{ }^{\circ} \mathrm{C}-30{ }^{\circ} \mathrm{C}$ for survival. High impermanence is frequent case of in vitro propagated plants because the artificially developed plants do not have functional stomata and possesses weaker roots with poorly developed cuticles than that of normal plants (32). Therefore, the plantlets developed artificially needs to gradually overcome the acclimatization process from the incubation room to greenhouse and then to the appropriate site. Eventually, the favorable outcome of an in vitro propagation of plants lies in their fortuitous establishment in soil or in other appropriate and favorable site (37). In the current investigation, $60 \%$ of plants lived acclimatization without any phenotypical aberrance which was also in concordance with our cytological investigation (38-40).

\section{Conclusion}

The current investigation presents the first report on micropropagation of $V$. borneensis through in vitro direct regeneration and multiplication of shoot from nodal explants. This study developed an optimized simple protocol for mass propagation revealing the nodal explants as best suited explants generating multiple shoots and the final acclimatized healthy plantlets in approximately 6-7 months (190-195 days). Optimum application of BAP along with TDZ produces multiple shoots which can be further cultured in shoot elongation media boosted with $\mathrm{BAP}+\mathrm{CW}$. To maintain its endurance, optimum relative humidity of $60-70 \%$ should be maintained during the whole acclimatization process until further transfer of the plants to suitable and favorable sites. The mass propagation protocol established here could be exploited for conservation of this critically endangered orchid.

\section{Acknowledgements}

The Authors highly acknowledge DST-FIST, Govt. of India sponsored infrastructural facilities of the Dept. of Botany, Gauhati University, India.

\section{Authors contributions}

SH carried out all the experiments, compiled and prepared the manuscript, BT designed the experiments, verified the findings and overall checked and edited the final manuscript.

\section{Compliance with ethical standards}

Conflict of interest: The author strongly confirms that this research is conducted with no conflict of interest.

Ethical issues: None.

\section{References}

1. Chowdhury S. Assam's Flora (Present status of Vascular Plants). Assam Science Technology and Environmental Council. 2005.

2. Borthakur SK, Hajra PK. Vanilla pilifera Holtt. (Orchidaceae) in Mikir Hill, Assam. Bulletin of Botanical Survey of India. 1976;18(14):228-30.

3. Deka K, Barua PS, Sharma B, Borthakur SK, Tanti B. Preventing extinction and improving conservation status of Vanilla borneensis Rolfe- A rare endemic and threatened orchid of Assam, India. Journal for Natural Conservation. 2017;37:39-46. https:// doi.org/10.1016/j.jnc.2017.03.001

4. Hasnu S, Saikia D, Sarma B, Tanti B. Karyotype analysis of Vanilla borneensis Rolfe-a critically endangered orchid of Assam, India. Journal of Advance Plant Science. 2020;10(2):24-30.

5. Barik SK, Rao BRP, Haridasan K, Adhikari D, Singh PP, Tiwary R. Classifying threatened species of India using IUCN criteria. Current Science. 2018;114(3):558-95.

6. Lubinsky P, Bory S, Hernandez JH, Kim SC, Gomez-Pompa A. Origins and Dispersal of Cultivated Vanilla (Vanilla planifolia Jacks. [Orchidaceae]). Economic Botany. 2008;62(2):127-38.

7. Alomia YA, Espinosa ATM, Flanagan NS, Otero JT. Seed viability and symbiotic seed germination in Vanilla spp. (Orchidaceae). Research Journal of Seed Science. 2017;10:43-52.

8. Gantait S, Mandal N, Bhattacharjyya S, Das PK, Nandy S. Mass multiplication of Vanilla planifolia with pure genetic identity confirmed by ISSR. International Journal of Plant Developmental Biology. 2009;3(1):18-23.

9. Sarma B, Tanti B. In- vitro regeneration of plantlets from nodal explants of Aristolochia saccata and Aristolochia cathcartii. European Journal of Biological Research. 2017;7:191-201.

10. Murashige T, Skoog F. A revised medium for rapid growth and bioassays with tobacco tissue cultures. Physiologia Plantarum. 1962;15:473-94.

11. Das P, Tanti B, Borthakur SK. In-vitro callus induction and indirect organogenesis of Brucea mollis Wall. ex Kurz - A potential medicinal plant of Northeast India. South African Journal of Botany. 2018;119:203-11.

12. Hore $\mathrm{P}$, Tanti B. Regeneration of plantlets from rhizome bud explants of Lasia spinosa (Lour.) Thwaites- A medicinal plants of Assam. International Journal of Life Science and Scientific Research. 2018;4:1736-43.

13. Duncan DB. Multiple range and multiple $f$ test. Biometrics. 1995;11:1-42.

14. Sasikumar B, Rema J, Ravindran PN. Vanilla, Indian Cocoa. Arecanut Spices Journal. 1992;16:6-10.

15. Giridhar P, Ravishankar GA. Efficient micropropagation of Vanilla planifolia Andr. under influence of thidiazuron, zeatin and coconut milk. Indian Journal of Biotechnology. 2004;3:113-18.

16. Gu Z, Arditti J, Nyman LP. Vanilla planifolia: Callus induction and plantlet production in-vitro. Lindleyana. 1978;2:48-52.

17. Davidonis G, Knorr D. Callus formation and shoot regeneration in Vanilla planifolia. Food Biotechnology. 1991;5:59-66.

18. Abebe Z, Mengesha A, Teressa A, Tefera W. Efficient in-vitro multiplication protocol for Vanilla planifolia using nodal explants in Ethiopia. African Journal of Biotechnology. 2009;8(24):6817-21.

19. Espinosa HEL, Gonza 'lez JMA, Rosas BG, Contreras ALC. In-vitro clonal propagation of Vanilla (Vanilla planifolia 'Andrews'). Horticulture Science. 2008;43(2):454-58.

20. Zuraida ABR, Izzati KHFL, Nazreena OA, ZalihaWSW, Radziah CMZC, Zamri, Z, Sreeramanan S. A simple and efficient protocol for the mass propagation of Vanilla planifolia. American Journal of Plant Science. 2013;4:1685-92. 
21. Giridhar P, Obul BR, Ravishankar GA. Silver nitrate influences invitro shoot multiplication and root formation in Vanilla planifolia Andr. Current Science. 2001;81:1166-70.

22. George PS, Ravishankar GA. In-vitro multiplication of Vanilla planifolia using axillary bud explants. Plant Cell Report. 1997;16:490 $-94$.

23. Bhojwani SS. A tissue culture method for propagation and low temperature storage of Trifolium repens genotypes. Physiologia Plantarum. 1981;52:187-90.

24. Sugla T, Purkayastha J, Singh SK, Solleti SK, Sahoo L. Micropropagation of Pongamia pinnata through enhanced axillary branching. In-vitro Cellular and Developmental Biology-Plant. 2007;43:409-14.

25. Biradar V, Inamdar A, Shamse A, Patil MS. In-vitro studies on the influence of different concentrations of growth regulators on economically important orchid, Vanilla planifolia. International Journal of Current Microbiology and Applied Science. 2016;5 (9):311-23.

26. Yong JWH, Ge L, Ng YF, Tan SN. The chemical composition and biological properties of coconut (Cocos nucifera L.) water. Molecules. 2009;14:5144-64.

27. Kalimuthu K, Senthilkumar R, Murugulatha N. Regeneration and mass multiplication of Vanilla planifolia Andr. - A tropical orchid. Current Science. 2006;91(10):1401-03.

28. Morwal G, Jadhav SJ, Shinde A, Mandge N, Mandge N. Conservation of Vanilla Planifolia by In-vitro micropropagation method. International Journal of Research Advent Technology. 2015;(EISSN: 2321-9637) Special Issue National Conference “ACGT 2015”, 13-14 February 2015.

29. Fasola F, Zimmerman RH, Fordhan I. Adventitious shoot formation on excised leaves of in-vitro grown shoots of apple cultivars. Plant Cell Tissue Organ Culture. 1989;16:75-87.

30. Bhagawata B, Vieiral LGF, Erickson LR. Stimulation of invitro shoot proliferation from nodal explants of Cassava by thidiazuron, benzyladenine and gibberellic acid. Plant Tissue \& Organ Culture. 1996;46:1-7.

31. Sankhla D, Davis TD, Sankhla N. In-vitro regeneration of silk tree (Albizzia julibrssin) from excised roots. Plant Cell Tissue Organ Culture. 1996;44:83-86.
32. Tan BC, Chin CF, Alderson P. Optimization of plantlet regeneration from leaf and nodal derived callus of Vanilla planifolia Andrews. Plant Cell Tissue Organ Culture. 2011;105:457-63.

33. Parihar S. In-vitro conservation protocol of Ceropegia bulbosa: An important medicinal and threatened plant species of Western Rajasthan. Plant Science Today. 2017;4(1):21-26.

34. Parihar S. In-vitro biochemical characterization of Caralluma edulis (Edgew.) Benth. and Hook. f. and Caralluma adscendens (Roxb.) R. Br.: Medicinally potent Indian plant species. Vegetos: An International Journal of Plant Research and Biotechnology. 2018;31:142-46.

35. Parihar S, Dwivedi NK. Comprehensive analysis of liquid and semisolid culture system for in-vitro propagation and conservation of Caralluma edulis: an appetite suppressant medicinal succulent of the indian thar desert. Plant Cell Biotechnology and Molecular Biology. 2019;20(21-22):1020-31.

36. Parihar S, Dwivedi NK. A note on an important edible, rare and the famine food plant of Indian Thar Desert: Glossonema varians (Stocks) Benth. ex Hook.f. Genetic Resources and Crop Evolution. 2020;67:1929-34.

37. Parihar S. Protein profling of regenerative and non regenerative callus cultures of Glossonema varians: a rare, endemic and edible plant of Indian Thar Desert. Vegetos: An International Journal of Plant Research and Biotechnology. 2020;33:385-89.

38. Baruah PS, Deka K, Sarma B, Das P, Borthakur SK, Tanti B. Assessment of few unexplored RET plant wealth of Assam, India. Journal of Advanced Plant Sciences. 2017;9(2):10-15.

39. Das P, Tanti B, Borthakur SK. Effect of 2, 4-D on callus induction at nodal and internodal explants of Brucea mollis Wall. ex Kurzan endangered plant of Northeast India. Bioscience Discovery. 2017;8(3):369-74.

40. Hasnu S, Deka K, Saikia D, Lahkar L, Tanti B. Morphotaxonomical and phytochemical analysis of Vanilla borneensis Rolfe - a rare, endemic and threatened orchid of Assam, India. Vegetos. 2021; https://doi.org/10.1007/s42535-021-00306-X

$\S \S \S$ 